Short communication

\title{
Dietary lysine deficiency increases the incorporation rate of nitrogen-free compounds in muscle of pacu (Piaractus mesopotamicus)
}

\author{
Eduardo Gianini Abimorad ${ }^{\mathrm{a}}$,*, Carlos Ducatti ${ }^{\mathrm{b}, 1}$, Daniela Castellani ${ }^{\mathrm{a}}$, Rosângela Kiyoko Jomori ${ }^{\mathrm{c}}$, \\ Maria Célia Portella $^{\mathrm{d}}$, Maria Márcia Pereira Sartori ${ }^{\mathrm{b}}$, Dalton José Carneiro ${ }^{\mathrm{d}}$ \\ a IP - Instituto de Pesca, Centro APTA do Pescado Continental, Cx. Postal 1052, 15025-620 São José do Rio Preto, SP, Brazil \\ b UNESP - Univ. Estadual Paulista, Instituto de Biociências, Centro de Isótopos Estáveis, Distrito de Rubião Junior s/n, 18618-970 Botucatu, SP, Brazil \\ c FAFRAM/FE - Faculdade Dr. Francisco Maeda/Fundação educacional, 14500-000 Ituverava, SP, Brazil \\ ${ }^{\mathrm{d}}$ UNESP - Univ. Estadual Paulista, Centro de Aquicultura, Via de Acesso Paulo Donato Castellane s/n, 14884-900 Jaboticabal, SP, Brazil
}

\section{A R T I C L E I N F O}

\section{Keywords:}

Amino acids

Stable isotopes

Muscle lipid and glycogen

Reaction progress variable

Turnover

\begin{abstract}
A B S T R A C T
Isotopic experiments are conducted to evaluate turnover rates in fish tissue, especially as a function of nutrition. In 2007, Cerling et al. proposed an approach they named the reaction progress variable, which among other functions, allows to correct for growth during the period of data collection and to treat the isotopic incorporation system as a linear function, irrespective of the growth rate model. The objective of present study was to apply "the reaction progress variable" approach to describe stable isotope turnover in muscle tissue of pacu fed a lysine-deficient and a lysine-supplemented diet in order to determine the incorporation rates of nitrogen-free compounds, considering the correction for increases in mass during turnover. Since in muscle tissue carbon compounds are proteins, nucleic acids, lipids and carbohydrates and nitrogen compounds include only proteins and nucleic acids, the incorporation rates of nitrogen-free compounds were calculated by the difference between the incorporation rates of carbon and nitrogen compounds. The $\delta^{13} \mathrm{C}$ and $\delta^{15} \mathrm{~N}$ values were adjusted for the increase in mass of fish to determine incorporation rate constants through linear fit. High turnover rates were observed when the increase in mass was considered. There was no effect of the diets on the incorporation rates of carbon compounds into muscle tissue of juvenile pacu. Fish fed the lysine-deficient diet exhibited a higher metabolic $\delta^{15} \mathrm{~N}$ turnover rate, probably because of the greater degradation of nitrogen compounds; consequently, the incorporation rate of nitrogen-free compounds was $1.23 \%$ day $^{-1}$. A higher incorporation rate of nitrogen compounds was observed in fish fed the lysine-supplemented diet and the incorporation rate of nitrogen-free compounds was therefore lower in this group $\left(0.05 \%\right.$ day $\left.{ }^{-1}\right)$. The incorporation rate of nitrogen-free compounds (e.g., lipids and glycogen) into muscle tissue was higher in juvenile pacu fed the lysine-deficient diet compared to animals receiving the lysine-supplemented diet. We therefore propose to adopt the reaction progress variable approach as a more useful tool for describing isotopic incorporation datasets.
\end{abstract}

\section{Introduction}

The use of stable isotopes, especially for the evaluation of turnover rates in animal tissues, has been indicated as an important tool to increase our understanding of metabolic processes in fish nutrition (Wolfe and Chinkes, 2005; Zuanon et al., 2006; Gamboa-Delgado and Le Vay, 2009; Abimorad et al., 2014). Most turnover studies conducted during the growth phase assume that the animals are growing exponentially, following the model proposed by Hesslein et al. (1993) to fit the data and describe isotope exchange in animal tissue, but considering a single- compartment or metabolic pool.
The reaction progress variable proposed by Cerling et al. (2007) normalizes isotope exchange by treating the system as a linear function. More recent studies have used this approach to describe isotopic incorporation rates in turnover with more than one-compartment/turnover pool (Martínez del Rio and Anderson-Sprecher, 2008; Warne et al., 2010). In addition to this approach, Cerling et al. (2007) proposed another model that permits corrections of $\delta$ values considering the increase in mass, regardless the animal growth model (e.g., constant, exponential or sigmoid). Thus, isotopic incorporation rates in animal tissues can be determined based on the relative contribution of growth and catabolism (Carleton and Martínez del Rio, 2010).

\footnotetext{
* Corresponding author.

E-mail address: abimorad@apta.sp.gov.br (E.G. Abimorad).

1 "in memoriam"
} 
The pacu (Piaractus mesopotamicus) is a migratory tropical fish native to the Paraná, Paraguay and Uruguay River Basin in South America (Saint-Paul, 1986). It is an important species for South American fish farming because of its easy adaptation to low-cost feed, in addition to its rapid growth and tasty meat (Jomori et al., 2003; Abimorad et al., 2007). This fish tends to accumulate fat over its growth period due to its migratory behaviour, but this depends on the feeding regime during its life cycle (Abimorad et al., 2010).

According to the literature, fish fed lysine-supplemented diets show better growth performance, less fat accumulation, and a slight increase in body protein content (Rodehutscord et al., 2000; Encarnação et al., 2004; Luo et al., 2006; Zhou et al., 2008; Hansen et al., 2011). These findings can be owed to several factors such as selective catabolism of amino acids and the lipotropic action of carnitine, of which lysine is a precursor (Dias et al., 2001; Ozório et al., 2002; Conceição et al., 2003). However, no studies have so far investigated the effect of dietary lysine supplementation on the incorporation rates of body fat or other energy reserves in pacu.

The objective of the present study was to evaluate the application of the reaction progress variable model to $\delta^{13} \mathrm{C}$ and $\delta^{15} \mathrm{~N}$ turnover in muscle tissue of juvenile pacu fed a lysine-deficient and a lysine-supplemented diet in order to determine the incorporation rates of nitrogen-free compounds (e.g., lipids and glycogen).

\section{Material and methods}

\subsection{Diets}

Two basal diets were formulated according to the digestible amino acid requirements of pacu determined by Abimorad et al. (2010). One diet, called PE, was used during the pre-experimental period for standardization of the carbon and nitrogen isotopic signatures in muscle tissue of juvenile pacu. Another diet formulated with $\mathrm{C}_{3}$ plant products was used to evaluate the effect of lysine based on carbon and nitrogen stable isotope turnover. This diet was subdivided into two dietary treatments: one diet deficient in lysine and another diet supplemented with lysine (Table 1). Details about the production of the experimental diets can be found in Abimorad et al. (2014).

\subsection{Animals and experimental conditions}

Prior to the beginning of the performance test, 1200 pacu juveniles (1-3 g) underwent a pre-experimental stage of 57 days. During this period, the animals were fed the PE diet for carbon and nitrogen isotope standardization in muscle tissue. After this stage, 240 juveniles $(10.2 \pm 1.3 \mathrm{~g})$ with standardized isotopic signatures based on the diet that they received (PE) were weighed and divided into eight tanks $(500 \mathrm{~L})$ to compose the two treatments and four replicates, with a density of 30 fish per tank. The groups of animals received the dietary treatments for 100 days to evaluate turnover through isotopic exchange.

The experiment was conducted in a recirculating water system as described by Abimorad et al. (2014).

\subsection{Sampling and isotope analysis}

Four fish per treatment (one per tank) were collected randomly and weighed on days $0,4,7,10,14,18,23,28,38,47,56,68,83$ and 100 after the beginning of the experiment. The objective of the measurement on day zero was to express the isotopic composition of the feed consumed before exchange, i.e., that of the PE diet.

Sampling of the muscle fragments of the fish and isotope analysis are described in Abimorad et al. (2014).
Table 1

Composition of the experimental diets.

\begin{tabular}{|c|c|c|c|}
\hline & \multicolumn{3}{|l|}{ Diet } \\
\hline & $\mathrm{PE}$ & $\begin{array}{l}\text { Lysine } \\
\text { deficient }\end{array}$ & Lysine supplemented \\
\hline \multicolumn{4}{|l|}{ Ingredient $(\%)$} \\
\hline $\begin{array}{l}\text { Fish meal (Tilapia processing } \\
\text { residue) }\end{array}$ & 7.00 & - & - \\
\hline Poultry by-product meal & 23.18 & - & - \\
\hline Yeast & 2.00 & - & - \\
\hline Corn gluten $(60 \% \mathrm{CP})$ & 11.00 & - & - \\
\hline Corn & 26.00 & - & - \\
\hline Sorghum & 26.00 & - & - \\
\hline Corn oil & 2.15 & - & - \\
\hline Soybean meal & - & 30.95 & 30.95 \\
\hline Wheat gluten & - & 7.70 & 7.70 \\
\hline Wheat bran & - & 28.46 & 28.46 \\
\hline Broken rice & - & 22.07 & 22.07 \\
\hline Fish oil & - & 4.91 & 4.91 \\
\hline Soybean oil & - & 1.00 & 1.00 \\
\hline $\begin{array}{l}\text { Vitamin and mineral } \\
\text { supplement }{ }^{\mathrm{a}}\end{array}$ & 0.75 & 0.75 & 0.75 \\
\hline Salt $(\mathrm{NaCl})$ & - & 0.25 & 0.25 \\
\hline Calcium carbonate & - & 0.90 & 0.90 \\
\hline Dicalcium phosphate & - & 1.95 & 1.95 \\
\hline L-lysine 78 & 1.17 & - & 0.90 \\
\hline DL-methionine 98 & - & 0.13 & 0.13 \\
\hline L-threonine & - & 0.03 & 0.03 \\
\hline Kaolin & 0.75 & 0.90 & - \\
\hline \multicolumn{4}{|l|}{ Composition (\%) } \\
\hline Dry matter & 90.7 & 91.8 & 91.8 \\
\hline Crude protein & 32.7 & 26.2 & 26.6 \\
\hline Ether extract & 8.2 & 8.4 & 8.3 \\
\hline Crude fiber & 3.4 & 6.1 & 6.2 \\
\hline Mineral matter & 6.9 & 7.1 & 6.4 \\
\hline Nitrogen-free extract & 39.5 & 44.0 & 44.3 \\
\hline \multicolumn{4}{|l|}{ Amino acids (\%) } \\
\hline Arginine & 1.84 & 1.65 & 1.68 \\
\hline Histidine & 0.59 & 0.61 & 0.62 \\
\hline Isoleucine & 1.14 & 1.00 & 1.02 \\
\hline Leucine & 3.27 & 1.90 & 1.93 \\
\hline Lysine & 2.41 & 1.22 & 1.93 \\
\hline Methionine & 0.46 & 0.36 & 0.35 \\
\hline Phenylalanine & 1.38 & 1.27 & 1.29 \\
\hline Threonine & 1.22 & 0.94 & 0.96 \\
\hline Valine & 1.46 & 1.15 & 1.17 \\
\hline Aspartic acid & 2.77 & 2.32 & 2.36 \\
\hline Glutamic acid & 4.90 & 6.11 & 6.22 \\
\hline Alanine & 2.67 & 1.14 & 1.16 \\
\hline Cystine & 0.27 & 0.42 & 0.43 \\
\hline Glycine & 2.41 & 1.12 & 1.14 \\
\hline Proline & 2.55 & 1.85 & 1.89 \\
\hline Serine & 1.50 & 1.30 & 1.32 \\
\hline Tyrosine & 1.01 & 0.81 & 0.82 \\
\hline Methionine + cystine & 0.73 & 0.78 & 0.78 \\
\hline \multicolumn{4}{|l|}{ Isotope signatures $(\delta \%)$} \\
\hline${ }^{13} \mathrm{C}$ & -14.05 & -27.31 & -27.06 \\
\hline${ }^{15} \mathrm{~N}$ & 4.03 & 1.86 & 1.48 \\
\hline
\end{tabular}

Partially republished from Abimorad et al. (2014). Elsevier License Number 3667221255308 .

a (enriched $\mathrm{kg}^{-1}$ ration): vitamins: $\mathrm{A}=1200 \mathrm{IU}, \mathrm{D} 3=3000 \mathrm{IU}, \mathrm{E}=150.0 \mathrm{mg}$, $\mathrm{K}=15.0 \mathrm{mg}, \quad \mathrm{B} 1=20.0 \mathrm{mg}, \quad \mathrm{B} 2=20.0 \mathrm{mg}, \quad \mathrm{B} 6=17.5 \mathrm{mg}, \quad \mathrm{B} 12=40.0 \mu \mathrm{g}$, $\mathrm{C}=300.0 \mathrm{mg}$, folic acid $=6.0 \mathrm{mg}$, pantothenic acid $=50.0 \mathrm{mg}$, biotin $=1.0 \mathrm{mg}$, niacin $=100.0 \mathrm{mg}, \quad$ choline $=500 \mathrm{mg}, \quad$ inositol $=125 \mathrm{mg}, \quad$ cobalt $=0.4 \mathrm{mg}, \quad$ copper $=17.5 \mathrm{mg}, \quad$ iron $=100.0 \mathrm{mg}, \quad$ manganese $=50.0 \mathrm{mg}, \quad$ calcium $=0.8 \mathrm{mg}, \quad$ sodium $=0.4 \mathrm{mg}$, zinc $=120.0 \mathrm{mg}$, antioxidant $=25.0 \mathrm{~g}$.

\subsection{Turnover and muscle incorporation of $\delta^{13} \mathrm{C}$ or $\delta^{15} \mathrm{~N}$}

To estimate the turnover rates (no growth) of $\delta^{13} \mathrm{C}$ and $\delta^{15} \mathrm{~N}$ in muscle tissue of juvenile pacu, a simple best-fit exponential function was used for the data (Fry and Arnold, 1982). 
$\delta^{t}=\left(\delta^{\mathrm{eq}}-\delta^{\mathrm{init}}\right) e^{-\lambda t}+\delta^{\mathrm{eq}}$

where $\delta^{t}$ is the stable isotope $\left(\delta^{13} \mathrm{C}\right.$ and $\left.\delta^{15} \mathrm{~N}\right)$ undergoing isotope exchange over time $t, \delta^{\text {init }}$ is the isotope value of muscle tissue in equilibrium with the initial diet; $\delta^{\mathrm{eq}}$ is the isotope value reached when the tissue is in equilibrium with a new diet, and $\lambda$ is the no growth turnover rate constant.

The corrections of the individual $\delta^{13} \mathrm{C}$ and $\delta^{15} \mathrm{~N}$ values considering the increase in mass $\left(\delta_{\text {new }}{ }^{t}\right)$ were calculated using the following expression (adapted from Cerling et al., 2007):

$\delta_{\text {new }}{ }^{t}=\frac{\left[\left(\delta^{\text {eq }} \times \mathrm{M}_{\text {new }}{ }^{t}\right)+\left(\delta^{t} \times \mathrm{M}^{\text {init }}\right)\right]}{\mathrm{M}^{t}}$

where $\mathrm{M}^{t}, \mathrm{M}_{\text {new }}{ }^{t}$ and $\mathrm{M}^{\text {init }}$ are the mass measured at time $t$, the new added mass since time 0 and the initial mass at time 0 , respectively; $\delta^{t}$ is the $\delta$ value measured at time $t$, and $\delta^{\text {eq }}$ is the equilibrium $\delta$ value $(t=$ infinite).

The reaction progress variable model proposed by Cerling et al. (2007) was used to linearize isotope exchange, plotting $\ln (1-F)$ as a function of time. This term $(1-F)$ describes the reaction progress, where $F=0$ at the beginning of the exchange reaction and $F=1$ in the final state. The authors thus deduced $\ln (1-F)=-\lambda t$, where $\lambda$ is the turnover rate constant corrected or not for growth.

After linearization and estimation of the turnover rates with $\lambda_{\mathrm{WG}}$ and no growth $\lambda_{\mathrm{NG}}$ (Fig. 1), the carbon and nitrogen compound incorporation rates were calculated:

IRCC $=\lambda^{13} \mathrm{C}_{\mathrm{WG}}-\lambda^{13} \mathrm{C}_{\mathrm{NG}}$

IRNC $=\lambda^{15} \mathrm{~N}_{\mathrm{WG}}-\lambda^{15} \mathrm{~N}_{\mathrm{NG}}$,

where IRCC is the incorporation rate of carbon compounds and IRNC is the incorporation rate of nitrogen compounds.

Since carbon compounds are proteins, nucleic acids, lipids and
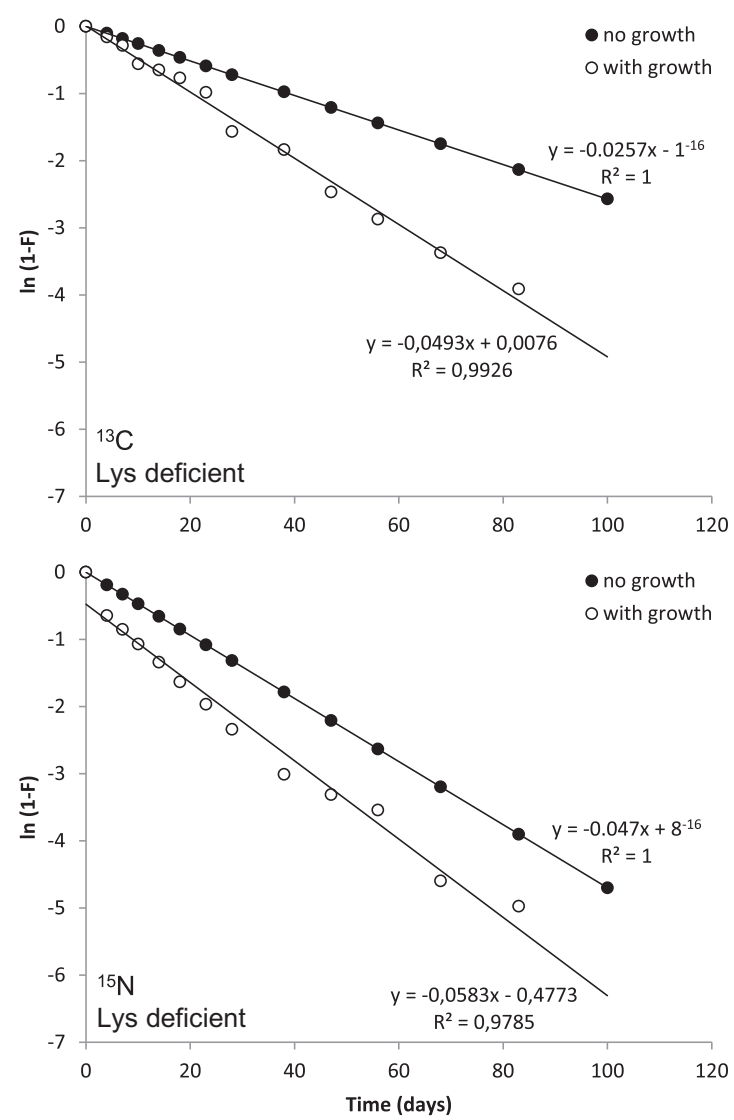

carbohydrates and nitrogen compounds include only proteins and nucleic acids, the incorporation rate of nitrogen-free compounds (IRNFC) was calculated as the difference between them:

IRNFC $=$ IRCC - IRNC.

The relative contribution of growth as a percentage of carbon and nitrogen compounds was determined by the ratio between incorporation rate and turnover rate corrected for growth:

$\% G^{13} C=\frac{\text { IRCC }}{\lambda^{13} \mathrm{C}_{\mathrm{WG}}}$ or $\% G^{15} N=\frac{\text { IRNC }}{\lambda^{15} \mathrm{~N}_{\mathrm{WG}}}$.

In addition, the incorporation of nitrogen-free compounds was calculated as percentage:

$\%$ INFC $=\% G^{13} C-\% G^{15} N$.

\subsection{Performance}

At the end of the experiment, all remaining fish were weighed for the determination of weight gain and feed conversion ratio:

weight gain $(\%)=($ final weight - initial weight $) /$ initial weight $\times 100$;

feed conversion ratio $=$ feed intake/weight gain .

The weight of animals collected during the experiment was used to calculate feed conversion and growth rate. The latter was given by fitting the weight data to the following growth model:

$W=W_{0} \times e^{k t}$

where $k$ is the growth rate, $W_{0}$ is the mean initial weight of the animals, $W$ is the weight of the animals on the day of sampling, and $t$ is the time in days.

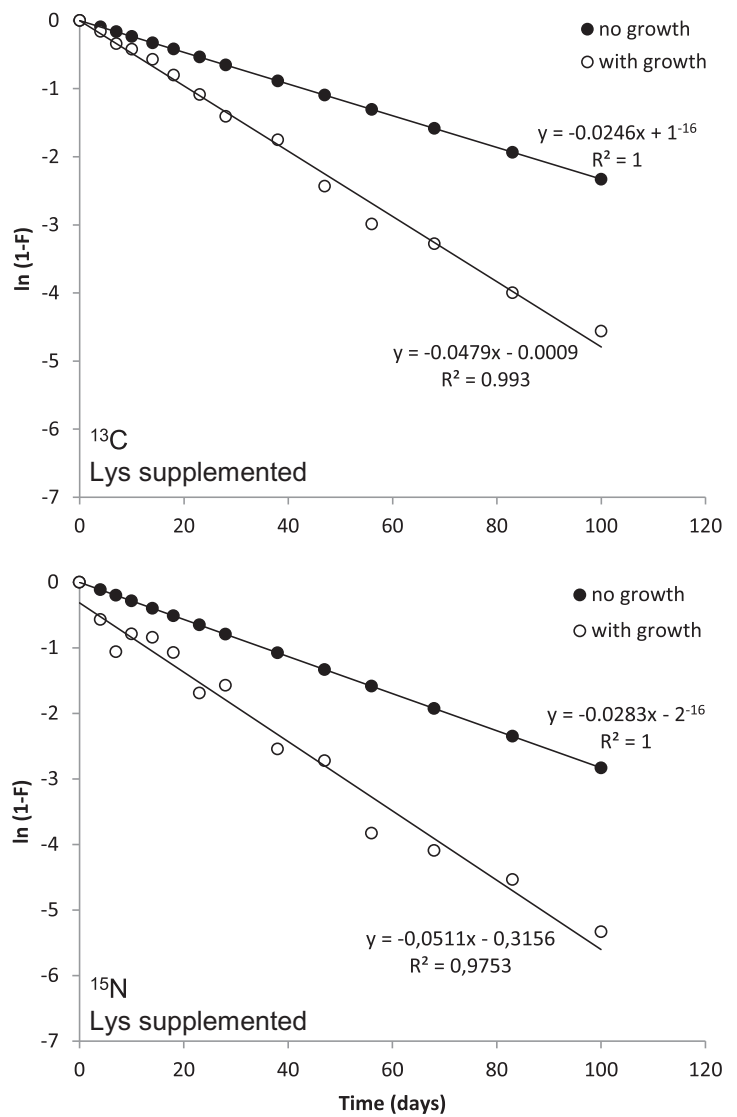

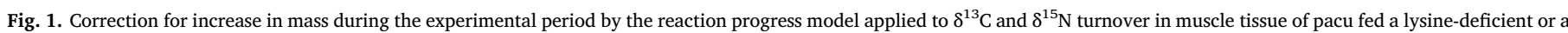
lysine-supplemented diet. 
Table 2

Productive performance of juvenile pacu fed an experimental diet. ${ }^{\mathrm{a}}$

\begin{tabular}{|c|c|c|c|}
\hline \multirow[t]{2}{*}{ Parameter } & \multicolumn{2}{|l|}{ Diet } & \multirow{2}{*}{$\begin{array}{l}\text { ANOVA } \\
P \text { value }\end{array}$} \\
\hline & Lysine deficient & Lysine supplemented & \\
\hline Mean initial weight (g) & $10.1 \pm 1.5$ & $10.2 \pm 1.5$ & 0.9256 \\
\hline Weight gain $(\%)^{\mathrm{b}}$ & $435.6 \pm 50$ & $472.4 \pm 37$ & 0.1910 \\
\hline Growth rate $\left(\text { day }^{-1}\right)^{\mathrm{c}}$ & $2.21 \pm 0.11$ & $2.24 \pm 0.13$ & 0.1868 \\
\hline Feed conversion ratio ${ }^{\mathrm{d}}$ & $1.18 \pm 0.02$ & $1.10 \pm 0.09$ & 0.1516 \\
\hline
\end{tabular}

Mean values of 4 replicates \pm standard deviation.

a Partially republished from Abimorad et al. (2014). Elsevier License Number 3667221255308

${ }^{\mathrm{b}}$ Weight gain $=($ final weight - initial weight $) /$ initial weight $\times 100$.

c Growth rate $(k)=$ fitting fish weight data to the exponential growth model $W=W_{0} \times \mathrm{e}^{k t}$.

${ }^{\mathrm{d}}$ Feed conversion ratio $=$ feed intake $/$ weight gain.

\subsection{Statistical analysis}

A completely randomized design consisting of two dietary treatments and four replicates was used. The productive performance parameters were evaluated by the Student $t$-test. For the determination of turnover and isotopic incorporation rates, the carbon and nitrogen isotope enrichment data (corrected or not for growth) in muscle of fish submitted to the different treatments were fitted by reaction progress variable modeling, using the Origin 6.0 Professional program (Microcal Software Origin 6.0 Professional, 1999). This model permits to measure the rates studied in absolute numbers. The occurrence of more than one compartment or metabolic pool was verified by the residual error of $\ln$ $(1-F)$ as a function of time, according to Ducatti et al. (2016).

\section{Results}

The isotopic standardization and growth performance results were partially republished from Abimorad et al. (2014). In summary, there was no difference $(P>0.05)$ in weight gain, feed conversion or growth rate between lysine-deficient and -supplemented dietary treatments (Table 2).

Evaluation of the residual error of $\ln (1-F)$ as a function of time (Ducatti et al., 2016) revealed the absence of more than one turnover compartment or pool in the models studied. Fig. 1 shows the reaction progress curves for $\delta^{13} \mathrm{C}$ and $\delta^{15} \mathrm{~N}$ turnover in muscle tissue corrected or not for the increase in mass during the experimental period.

In general, high turnover rates were observed when growth was considered $\left(\lambda_{\mathrm{WG}}\right)$ (Fig. 1 and Table 3 ). Dietary lysine did not affect the turnover rates of $\delta^{13} \mathrm{C}$ (corrected or not for growth) or the incorporation of carbon compounds (IRCC). On the other hand, an effect of dietary lysine was observed on the metabolic turnover rates of $\delta^{15} \mathrm{~N}\left(\lambda_{\mathrm{NG}}\right)$. Animals fed the lysine-deficient diet exhibited a higher metabolic turnover rate of $\delta^{15} \mathrm{~N}$ and a lower incorporation rate of nitrogen compounds (IRNC). Thus, a higher incorporation rate of nitrogen compounds was observed in fish fed the diet supplemented with lysine. Consequently, fish fed the deficient diet had a higher incorporation rate of nitrogen-free compounds (IRNFC) than animals receiving the lysine-
Table 4

Relative contribution of growth (\%G).

\begin{tabular}{lll}
\hline Relative contribution of growth (\%) & Diet & \\
\cline { 2 - 3 } & Lysine deficient & Lysine supplemented \\
\hline$\% \mathrm{G}^{13} \mathrm{C}$ & 48 & 49 \\
$\% \mathrm{G}^{15} \mathrm{~N}$ & 19 & 45 \\
$\% \mathrm{INFC}^{\mathrm{b}}$ & 29 & 4 \\
\hline
\end{tabular}

${ }^{\mathrm{a}}$ (Incorporation rate/turnover rate with growth) $\times 100$.

${ }^{b} \% I N F C$ (incorporation of nitrogen-free compounds) $=\% \mathrm{G}^{13} \mathrm{C}-\% \mathrm{G}^{15} \mathrm{~N}$.

supplemented diet (Table 3).

Another approach to evaluate the incorporation of nitrogen-free compounds is based on the relative contribution of growth or the increase in mass (\%). Table 4 shows the relative contribution of growth to nitrogen-free compounds for the two treatments. The relative contribution of the increase in mass to carbon compounds was $48 \%$ and $49 \%$ for fish fed the lysine-deficient and the lysine-supplemented diet, respectively, while the relative contribution of the increase in mass to nitrogen compounds was $19 \%$ and $45 \%$. The estimated relative contribution of growth to nitrogen-free compounds, given by the difference between the relative contribution of the increase in mass to the incorporation of carbon and nitrogen compounds, was $29 \%$ for fish fed the lysine-deficient diet versus only $4 \%$ for fish fed the lysine-supplemented diet.

\section{Discussion}

As previously reported by Abimorad et al. (2014), the period of 57 days for isotopic standardization was sufficient to stabilize isotopic signatures in muscle tissue of juvenile pacu. The same study also found no significant difference in productive performance between dietary treatments, but the authors reported that dietary lysine can physiologically modulate protein catabolism.

Higher metabolic turnover rates of $\delta^{15} \mathrm{~N}$ in muscle tissue of juvenile pacu fed lysine-deficient diets have been reported by Abimorad et al. (2014) who investigated turnover rates from growth and metabolism $(k$ $+m$ ). This finding might be explained by the high degradation of nitrogen compounds (muscle protein) to compensate for the dietary deficiency of lysine for protein resynthesis (Wolfe and Chinkes, 2005). The consequence is a high incorporation rate of nitrogen-free compounds (e.g., energy reserves) as observed in the present study. This indicates that dietary lysine deficiency promotes selective catabolism of amino acids in muscle and the accumulation of fat reserves (Ozório et al., 2002; Conceição et al., 2003), increasing nitrogen excretion (Abimorad et al., 2009). Inversely, lower fat accumulation and a slight increase in body protein content have been reported in several studies on fish fed lysine-supplemented diets (Rodehutscord et al., 2000; Encarnação et al., 2004; Luo et al., 2006; Zhou et al., 2008; Hansen et al., 2011). However, this effect has not been observed in Atlantic salmon (Salmo salar) (Anderson et al., 1992; Rathore et al., 2010).

Pacu tends to accumulate fat during its growth because of its migratory habit, but this accumulation depends on the feeding regime

Table 3

Turnover and incorporation rates of carbon and nitrogen compounds.

\begin{tabular}{|c|c|c|c|c|c|c|c|}
\hline \multirow[t]{2}{*}{ Diet } & \multicolumn{3}{|l|}{${ }^{13} \mathrm{C}$} & \multicolumn{3}{|l|}{${ }^{15} \mathrm{~N}$} & \multirow[t]{2}{*}{ IRNFC (IRCC-IRNC) } \\
\hline & $\lambda_{\mathrm{WG}}$ & $\lambda_{\mathrm{NG}}$ & IRCC & $\lambda_{\mathrm{WG}}$ & $\lambda_{\mathrm{NG}}$ & IRNC & \\
\hline Lys deficient & 0.0493 & 0.0257 & 0.0236 & 0.0583 & 0.0470 & 0.0113 & 0.0123 \\
\hline Lys supplemented & 0.0479 & 0.0246 & 0.0233 & 0.0511 & 0.0283 & 0.0228 & 0.0005 \\
\hline
\end{tabular}

IRCC (incorporation rate of carbon compounds) $=\lambda^{13} \mathrm{C}_{\mathrm{WG}}-\lambda^{13} \mathrm{C}_{\mathrm{NG}}$.

IRNC (incorporation rate of nitrogen compounds) $=\lambda^{15} \mathrm{~N}_{\mathrm{WG}}-\lambda^{15} \mathrm{C}_{\mathrm{NG}}$.

IRNFC (incorporation rate of nitrogen-free compounds) = IRCC - IRNC. 
during its life cycle. In a study determining the digestible lysine requirement of pacu, juveniles fed an adequate level of digestible lysine exhibited higher protein retention and lower body fat (Abimorad et al., 2010). Like the results of the present study, these findings show a reduction in the incorporation rate of nitrogen-free compounds by fish fed a diet supplemented with lysine. This observation may be related to the fact that lysine is a precursor in the biosynthesis of carnitine (Rebouche, 1992), which acts as a lipotrophic factor and thus contributes to the reduction in body fat deposition (Dias et al., 2001).

Rathore et al. (2010) observed an increase in carnitine in the liver of Atlantic salmon $(\approx 600 \mathrm{~g}$ ) fed diets containing an adequate level of lysine for the species compared to the group that received a lysinedeficient diet, but found no alterations in tissue lipid levels (muscle and liver). However, muscle glycogen was lower in fish fed the adequate lysine diet, a finding suggesting the occurrence of glycogenolysis for the release of energy to support increased growth (Gómez-Requeni et al., 2011). Although the effect of dietary lysine is directly related to lipid metabolism (Hansen et al., 2011), its effect on tissue glycogen levels has also been reported in the study of Rathore et al. (2010) on Atlantic salmon. In this respect, the present study also analyzed the effect of lysine on both nitrogen-free compounds: muscle lipid and glycogen; however, these compounds were not evaluated separately since their individual analysis may incur methodological problems mainly because of the extraction methods usually employed, in addition to possible inaccurate measurements as reported by Trueman et al. (2005) for lipids and by Beltrán et al. (2009) for glycogen. Although lipid is more representative (in mass) than glycogen in both muscle and liver (Rathore et al., 2010), muscle glycogen can be an important energy reserve that is more readily available than hepatic glycogen due to the large mass of muscle tissue that can account for approximately $60 \%$ of the animal's body weight (Houlihan et al., 1995).

Studies have shown that growth contributes $10 \%$ to the incorporation of carbon compounds in adult animals and up to $100 \%$ in rapidly growing animals, such as larvae and juveniles (Martínez del Rio et al., 2009). In the present study using juvenile pacu (mean initial weight of $10 \mathrm{~g}$ ), the results showed that growth contributed nearly $50 \%$ to the incorporation of carbon compounds into muscle. Dietary lysine had little effect on the relative contribution of growth to the incorporation of carbon compounds, while the relative contribution of growth to the incorporation of nitrogen compounds was $26 \%$ lower in fish fed the lysine-deficient diet.

The use of stable isotopes is a more refined technique to study nutrient retention because it permits the evaluation of turnover rates of key elements, indicating synthesis and catabolism of nutrients in tissue specific. Additionally, the reaction progress model is more useful way to describe biological turnover experiments than the exponential-fit method, especially when the animal is growing, with the advantage of correcting each sample independently of all other samples, and also allows to distinguish multiple turnover pools.

Taken together, this study demonstrates that the advantage of linearization and correction for increase in mass of the reaction progress variable applied to growing animals allowed to determine the incorporation rates of nitrogen-free compounds (lipids and glycogen) in muscle tissue of juvenile pacu. Fish fed the adequate lysine diet showed lower incorporation rates of nitrogen-free compounds $(0.05 \%$ per day) or lower contribution of growth to the incorporation of these compounds (4\%), while the lysine-deficient diet resulted in higher incorporation rates of nitrogen-free compounds into muscle tissue of juvenile pacu (1.23\% per day) or higher contribution of growth to the incorporation of these compounds (29\%). This approach will provide a new tool for future nutrient assimilation/incorporation studies in fish tissues during the growth phase as a function of feeding regime or diet quality.

\section{Acknowledgements}

We thank CNPq for granting a postdoctoral fellowship to the first author (Grant 505045/2008-7). This study is part of a Thematic Project financed by FAPESP (Grant 2008/57411-4).

\section{References}

Abimorad, E.G., Carneiro, D.J., Urbinati, E.C., 2007. Growth and metabolism of pacu (Piaractus mesopotamicus Holmberg 1887) juveniles fed diets containing different protein, lipid and carbohydrate levels. Aquac. Res. 38, 36-44.

Abimorad, E.G., Favero, G.C., Castellani, D., Garcia, F., Carneiro, D.J., 2009. Dietary supplementation of lysine and/or methionine on performance, nitrogen retention and excretion in pacu Piaractus mesopotamicus reared in cages. Aquaculture 295, 266-270.

Abimorad, E.G., Favero, G.C., Squassoni, G.H., Carneiro, D.J., 2010. Dietary digestible lysine requirement and essential amino acid to lysine ratio for pacu Piaractus mesopotamicus. Aquac. Nutr. 16, 370-377.

Abimorad, E.G., Ducatti, C., Castellani, D., Jomori, R.K., Portella, M.C., Carneiro, D.J., 2014. The use of stable isotopes to investigate the effects of supplemental lysine and methionine on protein turnover and amino acid utilization in pacu, Piaractus mesopotamicus, juveniles. Aquaculture 433, 119-124.

Anderson, S.J., Lall, S.P., Anderson, D.M., McNiven, M.A., 1992. Quantitative dietary lysine requirement of Atlantic salmon (Salmo salar) fingerlings. Can. J. Fish. Aquat. Sci. 50, 316-322.

Beltrán, M., Fernández-Borrás, J., Médale, F., Pérez-Sánchez, J., Kaushik, S., Blasco, J., 2009. Natural abundance of ${ }^{15} \mathrm{~N}$ and ${ }^{13} \mathrm{C}$ in fish tissues and the use of stable isotopes as dietary protein tracer in rainbow trout and gilthead sea bream. Aquac. Nutr. 15, 9-18.

Carleton, S.A., Martínez del Rio, C., 2010. Growth and catabolism in isotopic incorporation: a new formulation and experimental data. Funct. Ecol. 24, 805-812.

Cerling, T.E., Ayliffe, L.K., Dearing, M.D., Ehleringer, J.R., Passey, B.H., Podlesak, D.W., Torregrossa, A.M., West, A.G., 2007. Determining biological tissue turnover using stable isotopes: the reaction progress variable. Oecologia 151, 175-189.

Conceição, L.E.C., Grasdalen, H., Rønnestad, I., 2003. Amino acid requirements of fish larvae and post-larvae: new tools and recent findings. Aquaculture 227, 221-232.

Dias, J., Arzel, J., Corraze, G., Kaushik, J., 2001. Effects of dietary L-carnitine supplementation on growth and lipid metabolism in European seabass (Dicentrarchus labrax). Aquac. Res. 32, 206-215.

Ducatti, C., Sartori, M.M.P., Denadai, J.C., Costa, V.E., Pelícia, V.C., Macari, M., 2016 Modelling and determination of metabolic pools by stable carbon isotopes in the avian duodenal mucosa and albumen. J. Anim. Physiol. Anim. Nutr. 100, 77-84.

Encarnação, P., Langes, C., Rodehutscord, M., Hoehler, D., Bureau, W., Bureau, D.P., 2004. Diet digestible energy contents affects lysine utilization, but not dietary lysine requirements of rainbow trout, Oncorhynchus mykiss, for maximum growth. Aquaculture 235, 569-586.

Fry, B., Arnold, C., 1982. Rapid ${ }^{13} \mathrm{C} /{ }^{12} \mathrm{C}$ turnover during growth of brown shrimp (Penaeus aztecus). Oecologia 54, 200-204.

Gamboa-Delgado, J., Le Vay, L., 2009. Natural stable isotopes as indicators of the relative contribution of soy protein and fish meal to tissue growth in Pacific white shrimp (Litopenaeus vannamei) fed compound diets. Aquaculture 291, 115-123.

Gómez-Requeni, P., Vareilles, M., Kousoulaki, K., Jordal, A.E.O., Conceição, L.E.C., Rønnestad, I., 2011. Whole body proteome response to a dietary lysine imbalance in zebrafish Danio rerio. Comp. Biochem. Physiol. 6D, 178-186.

Hansen, A.C., Henre, G.I., Karlsen, Ø., Koppe, W., Rosenlund, G., 2011. Do plant-based diets for Atlantic cod (Gadus morhua L.) need additions of crystalline lysine or methionine? Aquac. Nutr. 17, 362-371.

Hesslein, R.H., Hallard, K.A., Ramlal, P., 1993. Replacement of sulfur, carbon, and nitrogen in tissue of growing broad whitefish (Coregonus nasus) in response to a change in diet traced by $\delta^{34} \mathrm{~S}, \delta^{13} \mathrm{C}$, and $\delta^{15} \mathrm{~N}$. Can. J. Fish. Aquat. Sci. 50, 2071-2076.

Houlihan, D.F., Carter, C.G., McCarthy, I.D., 1995. Protein synthesis in fish. In: Hochachka, P.W., Mommsen, I.D. (Eds.), Biochemistry and Molecular Biology in Fishes. Elsevier Science, Amsterdam, The Netherlands, pp. 191-219.

Jomori, R.K., Carneiro, D.J., Malheiros, E.B., Portella, M.C., 2003. Growth and survival of pacu Piaractus mesopotamicus (Holmberg, 1887) juveniles reared in ponds or at different initial larviculture periods indoors. Aquaculture 221, 277-287.

Luo, Z., Liu, Y.J., Mai, K.S., Tian, L.X., Tan, X.Y., Yang, H.J., Liang, G.Y., Liu, D.H., 2006. Quantitative L-lysine requirement of juvenile grouper Epinephelus coioides. Aquac. Nutr. 12, 165-172.

Martínez del Rio, C., Anderson-Sprecher, R., 2008. Beyond the reaction progress variable: the meaning and significance of isotopic incorporation data. Oecologia 156 $765-772$.

Martínez del Rio, C., Wolf, N., Carleton, S.A., Gannes, L.Z., 2009. Isotopic ecology ten years after a call for more laboratory experiments. Biol. Rev. 84, 91-111.

Microcal Software Origin ${ }^{\circledR} 6.0$ professional, 1999. Origin Data Analysis and Technical Graphics. Microcal Software, USA.

Ozório, R.O.A., Booms, G.H.R., Huisman, E.A., Verreth, J.A.J., 2002. Changes in amino acid composition in the tissues of African catfish (Clarias gariepinus) as a consequence of dietary L-carnitine supplements. J. Appl. Ichthyol. 18, 140-147.

Rathore, R.M., Liaset, B., Hevrøy, E.M., El-Mowafi, A., Espe, M., 2010. Lysine limitation alters the storage pattern of protein, lipid and glycogen in on-growing Atlantic salmon. Aquac. Res. 41, 751-759.

Rebouche, C.J., 1992. Carnitine function and requirements during the life cycle. FASEB J. 6, 3379-3386. 
Rodehutscord, M., Borchert, F., Gregus, Z., Pfeffer, E., 2000. Availability and utilization of free lysine in rainbow trout (Oncorhynchus mykiss). 2. Comparison of L-lysine- $\mathrm{HCl}$ and L-lysine sulphate. Aquaculture 187, 177-183.

Saint-Paul, U., 1986. Potential for aquaculture of South American freshwater fishes: a review. Aquaculture 54, 205-240.

Trueman, C.N., McGill, R.A.R., Guyard, P.H., 2005. The effect of growth rate on tissuediet isotopic spacing in rapidly growing animals. An experimental study with Atlantic salmon (Salmo solar). Rapid Commun. Mass Spectrom. 19, 3239-3247.

Warne, R.W., Gilman, C.A., Wolf, B.O., 2010. Tissue-carbon incorporation rates in lizards: implications for ecological studies using stable isotopes in terrestrial ectotherms.
Physiol. Biochem. Zool. 83, 608-617.

Wolfe, R.R., Chinkes, D.L., 2005. Whole body protein synthesis and breakdown. In: Wolfe, R.R., Chinkes, D.L. (Eds.), Isotope Tracers Metabolic Research: Principles and Practice of Kinetic Analysis, $2^{\text {nd }}$ edn. Wiley-Liss, MD, USA, pp. 299-323.

Zhou, X.Q., Zhao, C.R., Jiang, J., Feng, L., Liu, Y., 2008. Dietary lysine requirement of juvenile Jian carp (Cyprinus carpio var. Jian). Aquac. Nutr. 14, 381-386.

Zuanon, J.A.S., Pezzato, A.C., Pezzato, L.E., Passos, J.R.S., Barros, M.M., Ducatti, C., 2006. Muscle $\delta^{13} \mathrm{C}$ change in Nile tilapia (Oreochromis niloticus): effects of growth and carbon turnover. Comp. Biochem. Physiol. 145B, 101-107. 